\title{
The study of molybdenum-containing solutions by IR spectroscopy
}

\author{
(C) Alexey V. Klienkov, ${ }^{+}$Lyubov A. Petukhova, and Alexander A. Petukhov* \\ Department of Synthetic Rubber Technology. Kazan National Research Technological University. \\ Karl Marx St., 68. Kazan, 420015. Republic of Tatarstan. Russia. Phone: +7 (843) 231-42-16. \\ E-mail: klienkov.aleksey@gmail.com; petukhov-aa@yandex.ru
}

*Supervising author; ${ }^{+}$Corresponding author Keywords: monopropylene glycol, diethylene glycol, triethylene glycol, monomer, ammonium paramolybdate, molybdenum acid.

\section{Abstract}

Molybdenum compounds are widely used as catalysts for various chemical reactions, such as: oxidation, epoxidation, hydrogenation, reduction, etc. In particular, molybdenum compounds are used as a catalyst in the epoxidation of propylene with ethylbenzene hydroperoxide during the joint production of styrene and propylene oxide introduced into the industry as part of PJSC "Nizhnekamskneftekhim". We are working to verify the possibility of using glycol solutions, oxygen-containing inorganic compounds of molybdenum, such as molybdenum acid (MK), molybdenum anhydride (MA) and ammonium paramolybdate (PMA) as an epoxidation reaction catalyst. In the initial molybdenum compounds used to prepare the catalyst solutions, molybdenum is in the hexavalent state. The temperature treatment of these compounds in coordinating solvents, glycols, leads to their partial depolymerization and reduction to Mo(VI). Moreover, the more coordinating the solvent, the deeper these processes are flowed.

There are reports in the literature on the study of various molybdenum compounds in aqueous media and crystalline state by IR spectroscopy and Raman scattering.

It was found that the dissolution of MA, MK, and PMA in monoethylene glycol (MEG) is associated with the formation in the solution of compounds $\mathrm{Mo}(\mathrm{V}), \mathrm{Mo}(\mathrm{VI})$ of various molecular composition in the form of monomers, dimers, tetramers, and also in the form of the main components of hept- and octamers and higher molecular weight compounds. As the temperature rises, initially larger monomers of the octa- and hepta-form type transform into monomers of lower aggregation. All established patterns are analyzed by the example of PMA solutions in MEG.

\section{References}

[1] L.A. Petukhova. Synthesis of a molybdenum-containing catalyst for hydroperoxide epoxidation of olefins. Diss. Ph.D. Kazan. KNITU. 2011. P.131. (russian)

[2] A.V. Klienkov, and A.A. Petukhov. Obtaining molybdenyl glycolate using ethanol as a salting out solvent. Butlerov Communications. 2019. Vol.59. No.9. P.66-70. DOI: 10.37952/ROI-jbc-01/19-59-9-66

[3] Cotton, Wilkinson J. "Modern inorganic chemistry. Part 1". 1969. P.22.

[4] Yu.Ya. Kharitonov, Yu.F. Buslaev, A.A. Kuznetsova. Infrared absorption spectra of some molybdenum oxo compounds. J. Inorg. Chemistry. 1966. Vol.2. Iss.4. P.821-826. (russian)

[5] E.E. Criss, V.K. Rudenko, K.B. Yatsimirsky. Studying the reaction of reduction of molybdate to "blue" with various reducing agents. J. Inorg. Chemistry. 1971. Vol.16. Iss.8. P.2141-2153. (russian)

[6] Mijeke A. Infra-red Spektra of Glycjls Coordinated to Metal Ions. Bull. Chem. Soc. Japan. 1959. Vol.32. No.12. P.1381.

[7] Yu.A. Kharitonov, Yu.A. Buslaev. Infrared absorption spectra of oxofluorides of certain metals. Izv. USSR Academy of Sciences, ser. Chem. 1964. No.5. P.808-814. (russian)

[8] Yu.Ya. Kharitonov, A.O. Atovmyan. Infrared absorption spectra of the $\mathrm{K}_{2}\left[\mathrm{O}_{2}\left(\mathrm{NH}_{3}\right)_{4}\right] \mathrm{Cl}_{2}$ and $\mathrm{NH}_{4} \mathrm{NaMoO}_{3} \mathrm{C}_{2} \mathrm{O}_{4} \cdot 2 \mathrm{H}_{2} \mathrm{O}$ complexes. Izv. USSR Academy of Sciences. Ser. Chem. 1965. No.2. P.257. (russian)

[9] A.K. Babko, B.I. Nabivanets. Studying the state of molybdates in solution. The movement of ions during electrolysis. Solubility of molybdenum anhydride. J. Inorg. Chemistry. 1957. Vol.2. Iss.9. P.2085-2095. (russian)

[10] K. Nakamoto. IR spectra of inorganic and coordination compounds. Moscow: Mir. 1968. P.536. (russian) 